\title{
Effects of long-term fertilisation on aggregates and dynamics of soil organic carbon in a semi-arid agro-ecosystem in China
}

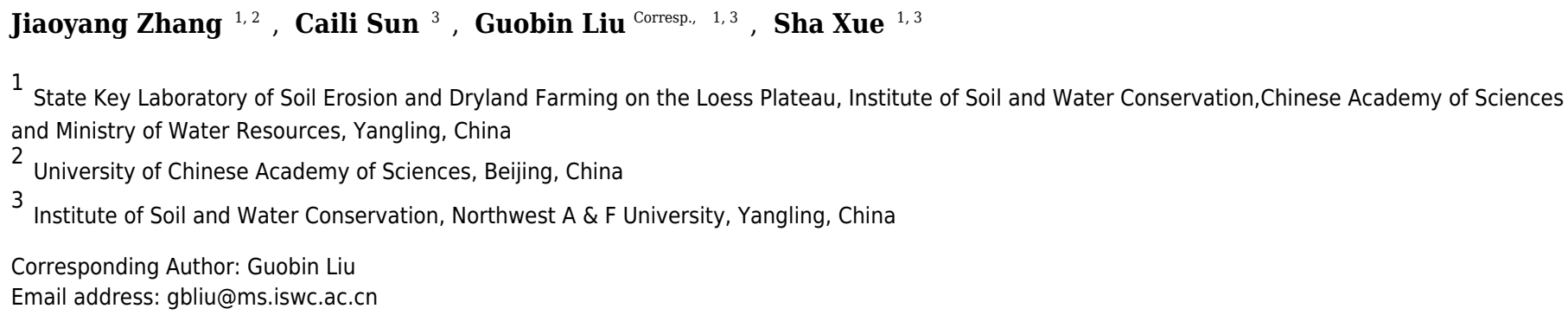

Background: Long-term fertilisation has a large influence on soil physical and chemical properties in agro-ecosystems. The effects on the distribution of aggregates, however, are not fully understood. We determined the dynamic change of the distribution of aggregates and soil organic carbon (SOC) content over time in a long-term field experiment established in 1998 on the Loess Plateau of China and illustrated the relationship between them.

Methods: We determined SOC content and the distribution of aggregates in nine fertiliser treatments: manure (M); nitrogen (N); phosphorus (P); $\mathrm{M}$ and $\mathrm{N} ; \mathrm{M}, \mathrm{N}$, and $\mathrm{P} ; \mathrm{M}$ and $\mathrm{P} ; \mathrm{N}$ and $\mathrm{P}$; bare land; and an unfertilised control. These parameters were then used for a path analysis and to analyse the fractal dimension $\left(D_{v}\right)$.

Results: The organic fertiliser increased SOC content. The proportions of 0.1-0.25 mm microaggregates and $0.25-0.5 \mathrm{~mm}$ macroaggregates were higher and the proportion of the $0.01-0.05 \mathrm{~mm}$ size class of the silt + clay fraction was lower in the treatments receiving organic fertiliser (M, MN, MNP, and MP) than that in the control, indicating that the addition of organic fertiliser promoted aggregation. The distribution of aggregates characterised by their fractal dimension $\left(D_{v}\right)$, however, did not differ among the treatments.

Discussion: $D_{v}$ was strongly correlated with the proportion of the $<0.002 \mathrm{~mm}$ size class of the silt + clay fraction that did not differ significantly among the treatments. The change in the distribution of aggregates was strongly correlated with SOC content, which could produce organic polymer binding agents to increase the proportion of larger particles. Long-term application of organic fertiliser is thus necessary for the improvement and maintenance of soil quality in semi-arid agricultural land when residues are removed. 


\section{Effects of Long-term Fertilisation on Aggregates and Dynamics of Soil}

\section{Organic Carbon in a Semi-arid Agro-ecosystem in China}

3 Jiaoyang Zhang ${ }^{12}$, Caili Sun ${ }^{3}$, Guobin Liu ${ }^{13 *}$, Sha Xue ${ }^{13}$

$4 \quad{ }^{I}$ State Key Laboratory of Soil Erosion and Dryland Farming on the Loess Plateau, Institute of

5 Soil and Water Conservation, Chinese Academy of Sciences and Ministry of Water Resources,

6 Yangling, Shaanxi 712100, PR China

$7 \quad{ }^{2}$ University of Chinese Academy of Sciences, Beijing 100101, PR China.

$8 \quad{ }^{3}$ Institute of Soil and Water Conservation, Northwest A \& F University, Yangling, Shaanxi

9 712100, PR China;

10

11

12 Address correspondence to Guobin Liu, Institute of Soil and Water Conservation,

13 Northwest A\&F University, Yangling 712100, P. R. China. E-mail: gbliu@ms.iswc.ac.cn 
17 Effects of Long-term Fertilisation on Aggregates and Dynamics of Soil

18

\section{Organic Carbon in a Semi-arid Agro-ecosystem in China}

Background: Long-term fertilisation has a large influence on soil physical and chemical properties in agro-ecosystems. The effects on the distribution of aggregates, however, are not fully understood. We determined the dynamic change of the distribution of aggregates and soil organic carbon (SOC) content over time in a long-term field experiment established in 1998 on the Loess Plateau of China and illustrated the relationship between them.

Methods: We determined SOC content and the distribution of aggregates in nine fertiliser treatments: manure $(\mathrm{M})$; nitrogen $(\mathrm{N})$; phosphorus $(\mathrm{P}) ; \mathrm{M}$ and $\mathrm{N} ; \mathrm{M}, \mathrm{N}$, and $\mathrm{P} ; \mathrm{M}$ and $\mathrm{P} ; \mathrm{N}$ and P; bare land; and an unfertilised control. These parameters were then used for a path analysis and to analyse the fractal dimension $\left(D_{\mathrm{v}}\right)$.

Results: The organic fertiliser increased SOC content. The proportions of $0.1-0.25 \mathrm{~mm}$ microaggregates and $0.25-0.5 \mathrm{~mm}$ macroaggregates were higher and the proportion of the 0.01 -

$0.05 \mathrm{~mm}$ size class of the silt + clay fraction was lower in the treatments receiving organic fertiliser (M, MN, MNP, and MP) than that in the control, indicating that the addition of organic fertiliser promoted aggregation. The distribution of aggregates characterised by their fractal dimension $\left(D_{\mathrm{v}}\right)$, however, did not differ among the treatments.

Discussion: $D_{\mathrm{v}}$ was strongly correlated with the proportion of the $<0.002 \mathrm{~mm}$ size class of the silt + clay fraction that did not differ significantly among the treatments. The change in the distribution of aggregates was strongly correlated with SOC content, which could produce 
37 organic polymer binding agents to increase the proportion of larger particles. Long-term

38 application of organic fertiliser is thus necessary for the improvement and maintenance of soil

39 quality in semi-arid agricultural land when residues are removed.

40

41

42

43

44

45 for atmospheric $\mathrm{CO}_{2}$, which has the potential to mitigate the effects of global emissions of

46 greenhouse gases (Brar et al., 2013; Yang et al., 2003). SOC content in agriculture can be

47 improved by the adoption of suitable management practices. Rudrappa et al. (2006) and Jaiarree

48

49

50

51 quality, highlighting the importance of soil management on particle aggregation and

52 disaggregation (Silva et al., 2014). Aggregate stability is generally strongly correlated with SOC

53 content, because the cohesion of aggregates is promoted mainly by organic polymer binding

54 agents (Haynes and Swift, 1990; Majumder et al., 2010) and by the physical trapping of particles

55 by fine roots and fungal hyphae (Helfrich et al., 2015; Chenu et al., 2000). Sequestration of SOC 
56

57

58

59

60

is mainly attributed to microaggregates $(0.05-0.25 \mathrm{~mm})$, because they are stabilised by persistent binding agents $(>0.25 \mathrm{~mm})$, and macroaggregates are stabilised by transient binding agents (Lugato et al., 2010; Yu et al., 2012).

The long-term application of organic fertiliser often increases SOC content (Yu et al., 2012; Saha et al., 2014) and the proportion of macroaggregates (Huang et al., 2010; Whalen et al., 2003). Reports of the effect of organic fertiliser on the distribution of microaggregates, however, have been inconsistent. Yu et al. (2012) and Tripathi et al. (2014) found that the application of organic fertiliser, compost and farmyard manure, respectively, significantly reduced the proportion of microaggregates. Interestingly, some studies have reported that organic fertiliser had no significant influence on the microaggregates relative to an unfertilised control (Chen et al., 2010; Liu et al., 2013). These different effects of organic fertiliser on the distribution of microaggregates may be attributed to the specific soil characteristics and climatic conditions ( $\mathrm{Yu}$ et al., 2012) and to the large range of size fractions of aggregate distribution determined by the classical wet-sieving method. Few studies have subdivided the microaggregates $(<0.25 \mathrm{~mm})$ into smaller size fractions, which impeded a deep understanding of the changes of microaggregates in response to fertilisation.

The analysis of soil-particle distribution by laser diffraction is now commonly used (Ryżak and Bieganowski, 2011; Xiao et al., 2014) and allows the categorisation of microaggregates into smaller size classes and provides detailed volume information for each size class. Fractal theory is an effective tool for describing complex and irregular geometry (Mandelbrot, 1983). Various 
76

77

soils have different particle compositions with irregular shapes and self-similar structures and have fractal characteristics (Tyler and Wheatcraft, 1989). Tyler and Wheatcraft (1992) proposed the weight fractal dimension $\left(D_{m}\right)$ for studying the fractal characteristics of soil structures. The calculation of $D_{m}$, however, assumes that particles of different sizes have the same density, but this assumption has been challenged by Martín and Montero (2002). This model was later developed for the volume fractal dimension $\left(D_{v}\right)$ based on laser diffraction to characterise soilparticle and aggregate distribution (Chen and Zhou, 2013; Wang et al., 2005). Xiao et al. (2014) and Zhao et al. (2006) reported that $D_{v}$ well described the changes in the stability of soil aggregates and in soil structure associated with vegetative succession.

Long-term experiments can provide more realistic scenarios for observing changes in soil properties and processes (Celik et al., 2010) and are thus suitable for studying the effect of fertilisation on soil quality. Some studies have determined the effect of long-term fertilisation on soil aggregates, but few studies have determined the dynamic changes of soil quality and structure for longer than 10 years. This study therefore determined SOC content and the distribution of soil aggregates of fields on the Loess Plateau in China that had been fertilised for 15 years to demonstrate the long-term trend of SOC content and fractal dimension. We hypothesised that the long-term application of organic or mineral fertilisers could significantly influence SOC content and the distribution of soil aggregates over time. The specific objectives were thus: (1) to observe the effect of fertilisation on SOC content, aggregate distribution, and $D_{v}$ and illustrate the relationship between them, and (2) to describe the dynamic changes in SOC 
96

97 Materials \& methods

98

99

100

101

102

103

104

105

106

107

108

109

110

111

112

113

114

content and $D_{v}$ over 15 years.

\section{Experimental site}

This study was part of an on-going long-term field fertilisation experiment established in 1998 at the Ansai National Field Scientific Observation and Research Station for Farmland Ecosystems, Shaanxi province, China $\left(36^{\circ} 51^{\prime} 30^{\prime \prime} \mathrm{N}, 109^{\circ} 19^{\prime} 23^{\prime \prime} \mathrm{E}\right)$. The station is at an altitude of 1068-1309 $\mathrm{m}$ a.s.1. and has a temperate semi-arid climate with a mean annual temperature of 8.8 ${ }^{\circ} \mathrm{C}$ and a mean annual rainfall of $500 \mathrm{~mm}$. The soil is a Huangmian soil, which is classified as a Calcic Cambisol (FAO/UNESCO/ISRIC, 1988), originating from wind-deposited loessial parental material and characterised by yellow particles, an absence of bedding, a silty texture, looseness, macroporosity, and wetness-induced collapsibility (Zhu et al., 2010). The basic soil characteristics to a depth of $20 \mathrm{~cm}$ were: organic-matter content of $15.54 \mathrm{~g} \mathrm{~kg}^{-1}$, total nitrogen $(\mathrm{N})$ content of $0.57 \mathrm{~g} \mathrm{~kg}^{-1}$, total phosphorus (P) content of $0.63 \mathrm{~g} \mathrm{~kg}^{-1}$, available $\mathrm{N}$ content of 28.99 $\mathrm{mg} \mathrm{kg}{ }^{-1}$, available $\mathrm{P}$ content of $2.49 \mathrm{mg} \mathrm{kg}^{-1}$, available potassium (K) content of $84.86 \mathrm{mg} \mathrm{kg}^{-1}$, $\mathrm{pH} 8.6$, and bulk density of $1.5 \mathrm{~g} \mathrm{~cm}^{-3}$.

\section{Sampling and processing}

The long-term experiment had a triplicate randomised complete block design with an area of $14 \mathrm{~m}^{2}$ for each plot. Each block contained nine treatments: manure (M), N, P, M and N (MN), $\mathrm{M}, \mathrm{N}$, and $\mathrm{P}(\mathrm{NMP}), \mathrm{M}$ and $\mathrm{P}(\mathrm{MP}), \mathrm{N}$ and $\mathrm{P}(\mathrm{NP})$, unfertilised bare land (BL), and an 
115

116

117

118 119

unfertilised control (CK) (Fig. 1). BL had not been sown or fertilised, and CK was sown but not fertilised. $\mathrm{N}$ was added as urea, $\mathrm{P}$ was added as superphosphate, and the farmyard manure consisted of the faeces and urine from domestic sheep. The contents of organic matter, $\mathrm{N}$, and $\mathrm{P}$ in the faeces were $25.7,0.75$, and $0.54 \%$, respectively. The contents of $\mathrm{N}$ and $\mathrm{P}$ in the urine were 1.4 and $0.45 \%$, respectively. The amounts of the fertilisers applied in the treatments are presented in Table 1. P, M, and $20 \%$ of the $\mathrm{N}$ were applied together as seed fertilisers, and the remaining $80 \%$ of the $\mathrm{N}$ was top-dressed between the large-bell and tasselling stages. The experiment had a three-year rotation, with a sequence of Glycine max-Zea mays-Z. mays, beginning with G. max in the autumn of 1998. The last crops of Z. mays (cv. QiangSheng 101) were seeded on 29 April 2012 at a rate of $52.5 \mathrm{~kg} \mathrm{ha}^{-1}$, and the plant density was about 51000 plants ha ${ }^{-1}$. The crops were manually harvested, and the aboveground residues were removed in October.

\section{Sampling}

The soil was sampled annually in October from 1998 to 2012 to a depth of $20 \mathrm{~cm}$. Three replicate soil samples were randomly excavated in each plot using a soil drill (diameter, $4 \mathrm{~cm}$ ) and then mixed to produce a composite sample. The samples for 1998-2012 were used for the analysis of changes over time. The samples for 1998-2011 (126 samples) had been stored in the station's soil library and were collected from one of the three replicate treatment plots. The samples for 2012 (27 samples) were used to examine the effects of fertilisation on aggregate distribution, $D_{\mathrm{v}}$, and SOC content. Visible plant residues were removed, and the samples were 
135

136

137

138

139

140

141

142

143

144

145

146

147

148

149

150

151

152

manually broken into fragments $<10 \mathrm{~mm}$ and air-dried at room temperature. Each sample was

passed through a 1-mm sieve for determining the distribution of the aggregates, and a subsample was then ground to pass through a $0.25-\mathrm{mm}$ sieve for the determination of total SOC content.

\section{Determination of aggregate distribution}

The soil samples were soaked in distilled water for $24 \mathrm{~h}$ and mechanically dispersed by ultrasonication for $5 \mathrm{~min}$ (Xiao et al., 2014). The samples were analysed with a Longbench Mastersizer 2000 (Malvern Instruments, Malvern, England).

Determination of SOC content

SOC content was determined by Walkley and Black dichromate oxidation (Nelson and

Sommers, 1982).

$D_{v}$ of aggregates

$D_{\mathrm{v}}$ was calculated as:

where $r$ is the particle diameter, $R_{i}$ is the diameter of size class $i, V\left(r<R_{i}\right)$ is the total volume of particles with diameters $<R_{i}, V_{T}$ is the total volume of particles, $R_{\max }$ is the maximal particle diameter, and $D_{v}$ is the volume fractal dimension. Logarithms were derived for both sides of the equation, and $D_{v}$ was obtained from the slopes of the double-logarithmic curves that fit the data. 

not significantly contribute to $D_{v}$ at $P=0.10$ were therefore not included in the regression model.

The indirect effects are determined from the product of the simple correlation coefficient

$$
r_{29}=r_{12} P_{19}+\mathrm{P}_{29}+r_{23} P_{39}+r_{24} P_{49}+r_{25} P_{59}+r_{26} P_{69}+r_{27} P_{79}+r_{28} P_{89}
$$


174

175

176

177

178

179

180

181

182

183

184

185

186

187

188

189

190

191

192

$$
r_{39}=r_{13} P_{19}+r_{23} P_{29}+P_{39}+r_{34} P_{49}+r_{35} P_{59}+r_{36} P_{69}+r_{37} P_{79}+r_{38} P_{89}
$$

$$
r_{49}=r_{14} P_{19}+r_{24} P_{29}+r_{34} P_{39}+P_{49}+r_{45} P_{59}+r_{46} P_{69}+r_{47} P_{79}+r_{48} P_{89}
$$$$
r_{59}=r_{15} P_{19}+r_{25} P_{29}+r_{35} P_{39}+r_{45} P_{59}+P_{59}+r_{56} P_{69}+r_{57} P_{79}+r_{58} P_{89}
$$

$$
r_{69}=r_{16} P_{19}+r_{26} P_{29}+r_{36} P_{39}+r_{46} P_{49}+r_{56} P_{59}+P_{69}+r_{67} P_{79}+r_{68} P_{89}
$$

$$
r_{79}=r_{17} P_{19}+r_{27} P_{29}+r_{37} P_{39}+r_{47} P_{49}+r_{57} P_{59}+r_{67} P_{69}+P_{79}+r_{78} P_{89}
$$$$
r_{89}=r_{18} P_{89}+r_{28} P_{29}+r_{38} P_{39}+r_{48} P_{49}+r_{58} P_{59}+r_{68} P_{69}+r_{78} P_{79}+P_{89}
$$

where $r_{i j}$ is the simple correlation coefficient between aggregate size class and $D_{v}, P_{i j}$ is the path coefficient between aggregate size class and $D_{v}$ (direct effects), and $r_{i j} P_{i j}$ is the indirect effect of aggregate size class on $D_{v}$. Subscript designations 1 to 9 represent the $<0.002,0.002-0.005$, 0.005-0.01, 0.05-0.1, 0.1-0.2, 0.2-0.25, 0.25-0.5, 0.5-1 mm aggregates and $D_{v}$, respectively. The residual, $U$, is an unmeasured variable in the path model that represents the unexplained part of an observed variable and is calculated as (Ige et al., 2007):

$$
U=\sqrt{1-R^{2}}
$$

where $R^{2}$ is the coefficient of determination of the multiple regression model between aggregate size classes and $D_{v}$.

The coefficient of determination for each factor denotes the degree of relative determination between cause and effect, which can be determined by (Bai et al., 2014; Chen et al., 2014):

$$
D_{y x i x j}=\left(P_{y i}\right)^{2}, \quad(i=j) ; \quad D_{y x i x j}=2 P_{y i} \times P_{y j} \times r_{i j}, \quad(i, j=1,2, \ldots, n, i<j)
$$

where $D_{y x i x j}$ is the coefficient of determination, and $y$ is $D_{v}$. 
193

194

195

196

197

\section{Statistical analyses}

One-way analyses of variation tested the differences between the various fertilisation treatments. Pearson correlation coefficients were calculated to analyse the relationships among aggregates, $D_{v}$, and SOC content. Duncan tests separated the means of these variables at $P<0.05$. All statistical analyses were conducted using the R statistical package (version 3.1.0).

\section{Results}

Effects of fertilisation treatments on SOC content, aggregate distribution, and $D_{v}$ SOC content was significantly higher in the treatments receiving organic fertiliser $(\mathrm{M}, \mathrm{MN}$, $\mathrm{MP}$, and MNP) than in the treatments receiving mineral fertiliser (N, NP, and P) or in BL or CK. SOC content did not differ significantly among BL, CK, N, NP, and P. The 0.01-0.05 size class of the silt + clay fraction and $0.05-0.1 \mathrm{~mm}$ microaggregates represented $>50 \%$ of the total soil aggregates (Table 2). The proportion of the 0.01-0.05 $\mathrm{mm}$ size class of the silt + clay fraction was the lowest in $\mathrm{M}$, and the proportion of $0.1-0.25 \mathrm{~mm}$ microaggregates was significantly higher in $\mathrm{M}$ than $\mathrm{CK}$. The proportion of $0.25-0.5 \mathrm{~mm}$ macroaggregates was significantly higher in the treatments receiving organic fertiliser (M, MN, MNP, and MP) than CK. In contrast, the distribution of aggregates in the treatments receiving mineral fertilisers $(\mathrm{N}, \mathrm{NP}$, and $\mathrm{P})$ and $\mathrm{BL}$ did not differ significantly from that in CK. $D_{v}$ did not differ significantly among the nine treatments.

\section{Correlations among aggregates, $D_{v}$, and SOC content}

The proportions of all size classes of the silt + clay fraction were positively correlated with 
213 each other, except between the 0.01-0.05 $\mathrm{mm}$ and $<0.002 \mathrm{~mm}$ and 0.005-0.01 $\mathrm{mm}$ size classes,

214 and were negatively correlated with the proportions of micro- and macroaggregates $(0.05-1 \mathrm{~mm})$,

215 except between the 0.2-0.25 and 0.002-0.005 and 0.01-0.05 mm size classes (Table 3). The

216 proportion of $0.05-0.1 \mathrm{~mm}$ microaggregates was positively correlated with the proportions of

$2170.1-0.2 \mathrm{~mm}$ microaggregates and macroaggregates $(0.25-1 \mathrm{~mm})$, the proportion of $0.1-0.2 \mathrm{~mm}$

218 microaggregates was positively correlated with the proportion of macroaggregates, and the

219 proportion of $0.25-0.5 \mathrm{~mm}$ macroaggregates was positively correlated with the proportion of 0.5 -

$2201 \mathrm{~mm}$ macroaggregates. $D_{v}$ was correlated positively with the proportion of the $<0.01 \mathrm{~mm}$ size

221 class of the silt + clay fraction and negatively with the proportions of the $0.01-0.05 \mathrm{~mm}$ size class

222 of the silt + clay fraction and 0.2-0.25 mm microaggregates. SOC content was correlated

223 negatively with the proportion of the $<0.05 \mathrm{~mm}$ size class of the silt + clay fraction and

224 positively with the proportions of micro- and macroaggregates $(0.05-1 \mathrm{~mm})$.

225

226

227

228

229

230

231

232

\section{Path analysis for aggregates and $D_{v}$}

A $U$ (uncorrected residue) of 0.054 and an $R^{2}$ of 0.997 indicated a small unexplained part of the observed variable in the path model, and the path analysis explained $99.7 \%$ of the variability associated with $D_{v}$ (Table 4$)$. The path coefficients (underlined in Table 4) indicated that all selected aggregate classes had significant direct effects on $D_{v}(P<0.01)$. The magnitude of the path coefficients indicated that silt + clay fraction $(<0.002 \mathrm{~mm})\left(P_{19}=0.887\right)$ was the most important causal factor in predicting $D_{v}$, followed by the $0.002-0.005 \mathrm{~mm}$ size class of the silt + clay fraction $\left(P_{29}=0.368\right)$. The direct effect of the $<0.002 \mathrm{~mm}$ size class of the silt + clay fraction 
$233(0.724)$ on $D_{v}$ was larger than its total indirect effects $(-0.132)$, and the direct and total indirect

234 effects of the $0.002-0.005 \mathrm{~mm}$ size class of the silt + clay fraction on $D_{v}$ were comparable $(0.368$

235 and 0.277 , respectively). The total indirect effects of the $0.005-0.01 \mathrm{~mm}$ size class of the silt +

236 clay fraction $(0.586)$ on $D_{v}$, however, were larger than the direct effects $(0.055)$. The indirect

237 effects of the $0.002-0.01 \mathrm{~mm}$ size classes of the silt + clay fraction on $D_{v}$ due to the $<0.002 \mathrm{~mm}$

238 size class were large $\left(r_{12} P_{19}=0.749\right.$ and $\left.r_{13} P_{19}=0.732\right)$.

239 The $<0.002 \mathrm{~mm}$ size class of the silt + clay fraction had the highest coefficient of

240 determination $\left(D_{y \times 1 \times 1}=0.787\right)$, followed by correlations between the $<0.002 \mathrm{~mm}$ size class of the

241 silt + clay fraction and $0.25-0.5 \mathrm{~mm}$ macroaggregates $\left(D_{y x 1 x 7}=0.674\right)$, the $<0.002$ and $0.002-0.005$

$242 \mathrm{~mm}$ size classes of the silt + clay fraction $\left(D_{y x 1 \times 2}=0.653\right)$, and the $<0.002$ and $0.01-0.05 \mathrm{~mm}$ size

243 classes of the silt + clay fraction $\left(D_{y x 1 x 8}=0.486\right)$. The other coefficients of determination were

244 low (Table 5).

245 Changes of SOC content and $D_{v}$ over time

246 The path graph clearly identified the changes of SOC content and $D_{v}$ from 1998 to 2012

247 (Fig. 3). SOC content tended to increase over time in the treatments receiving organic fertiliser

248 (M, MN, MNP, and MP) but not in the treatments receiving mineral fertilisers or in BL or CK.

$249 D_{v}$ did not change over time except in BL, where it tended to increase. 
250

251

252

253

254

255

256

257

258

259

260

261

262

263

264

265

266

267

268

269

\section{Discussion}

\section{Effect of fertilisation on SOC content, aggregate distribution and $D_{v}$}

SOC content did not differ significantly between $\mathrm{CK}$ and BL and the treatments receiving

mineral fertiliser. The 15-year application of organic fertiliser significantly increased SOC

content relative to the treatments receiving mineral fertiliser. The plots in this study were

conventionally tilled, and the soybean and maize straw was removed when the crops were

harvested, indicating that the increase in SOC content was mostly due to the application of

organic fertiliser, which has abundant humic material that improves SOC content, physical

properties, and other aspects of the soil such as $\mathrm{N}$ and $\mathrm{P}$ contents (Haynes and Naidu, 1998). The

application of organic fertiliser can also stimulate the development of roots in regions with poor

soil, such as the Loess Plateau (Banger et al., 2009); up to $40 \%$ of newly photosynthesised

carbon is released into soil by roots, thereby increasing the pool of active organic carbon

(Kuzyakov and Cheng, 2001).

Long-term fertilisation, especially with organic fertiliser, can have a large influence on the distribution of soil aggregates in agro-ecosystems (Miao et al., 2009; Plaza-Bonilla et al., 2013;

Tripathi et al., 2014). Application of M alone or in combination with mineral fertiliser (MN,

$\mathrm{MNP}$, and MP) increased the proportions of 0.1-0.25 $\mathrm{mm}$ microaggregates (even though the

increases were not significant among $\mathrm{MN}, \mathrm{MNP}$, and $\mathrm{MP}$ ) and 0.25-0.5 mm macroaggregates

and correspondingly decreased the proportion of the $0.01-0.05 \mathrm{~mm}$ size class of the silt + clay

fraction. In contrast, the distribution of aggregates relative to $\mathrm{CK}$ was not significantly affected 
by the treatments with only mineral fertiliser. The application of organic fertiliser was thus quite conducive to the aggregation of soil particles. Our results were consistent with previous results by Miao et al. (2009) who reported that the continual addition of organic fertiliser usually increased SOC content and microbial activity and had a positive effect on aggregation on the Songnen Plain in northwestern China. Tripathi et al. (2014), however, reported a decrease in the proportion of microaggregates under 41 years of fertilisation in a tropical agro-ecosystem in

China. A study conducted in Nanchang reported that organic fertiliser did not significantly affect microaggregates (Liu et al., 2013). These different results of the distribution of microaggregates may be attributed to the specific soil characteristics and climatic conditions. The application of mineral fertilisers, however, can have little impact on SOC content unless used in conjunction with no tillage and residue management (Lal, 2004; Rudrappa et al., 2006; Yang et al., 2003).One study even suggested that the long-term application of mineral fertilisers would likely degrade small macroaggregates into microaggregates, or even into the silt and clay fraction, and can lead to disaggregation (Chen et al. 2010). $D_{v}$ could not distinguish among the various treatments, even though it can well describe the changes in the stability of aggregates and soil structure associated with vegetative succession the $<0.002 \mathrm{~mm}$ size class of the silt + clay fraction (Table 3 ) that did not differ significantly among the treatments (Table 2). The proportions of the $0.002-0.01 \mathrm{~mm}$ size classes of the silt + clay fraction were also strongly correlated with $D_{v}$, but these correlations were mostly partitioned 
291 The path analysis indicated that the total indirect effect of the $0.002-0.01 \mathrm{~mm}$ size classes of the

292 silt + clay fraction on $D_{v}$ was mainly due to the $<0.002 \mathrm{~mm}$ size class, with coefficients of 0.732

293 and 0.749 , respectively. The higher direct effect of the $<0.002 \mathrm{~mm}$ size class of the silt + clay

294 fraction on $D_{v}(0.887)$ and the total indirect effect of the $0.002-0.01 \mathrm{~mm}$ size classes on $D_{v}$ due to

295 the $<0.002 \mathrm{~mm}$ size class matched the highest positive correlation coefficient between the $<0.002$

$296 \mathrm{~mm}$ size class and $D_{v}$, corresponding to the highest coefficient of determination of the $<0.002$

$297 \mathrm{~mm}$ size class $\left(D_{y x 1 x 1}=0.787\right)$, the large coefficients of determination of the correlations between

298 the $<0.002 \mathrm{~mm}$ size class of the silt + clay fraction and 0.25-0.5 mm macroaggregates

$299\left(D_{y x 1 x 7}=0.674\right)$, between the $<0.002$ and $0.002-0.005 \mathrm{~mm}$ size classes of the silt + clay fraction

$300\left(D_{y x 1 \times 2}=0.653\right)$, and between the $<0.002$ and $0.01-0.05 \mathrm{~mm}$ size classes of the silt + clay fraction

$301\left(D_{y x 1 x 8}=0.486\right)$. Our result was in agreement with previous studies by Tang et al. (2013) and Zhao

302 et al.(2006). Xiao et al. (2014) also demonstrated that $D_{v}$ was positively correlated with the

303 proportion of the $<0.002 \mathrm{~mm}$ size class of the silt + clay fraction.

304

305

306

307

308

309

310

\section{Correlations between aggregates, $D_{v}$, and SOC content}

The proportion of the silt + clay fraction $(<0.05 \mathrm{~mm})$ was generally negatively correlated with the proportions of micro- and macroaggregates $(0.05-1 \mathrm{~mm})$, but the proportions of some size classes in the $0.05-1 \mathrm{~mm}$ fractions (micro- and macroaggregates) were positively correlated, indicating that larger aggregates formed at the expense of the silt and clay fraction and vice versa and that aggregates $>0.05 \mathrm{~mm}$ may stimulate each other to reaggregate. This phenomenon was demonstrated by Su et al. (2006), who found that long-term application of organic fertiliser 
311 significantly increased the proportions of both $>2$ and $0.25-2 \mathrm{~mm}$ aggregates. Chen et al. (2010)

312 demonstrated that the application of mineral fertiliser increased the proportion of $<0.25 \mathrm{~mm}$

313 microaggregates and decreased the proportion of $0.25-2 \mathrm{~mm}$ macroaggregates.

314 SOC content in our study was correlated negatively with the proportion of the silt + clay

315 fraction $(<0.05 \mathrm{~mm})$ and positively with the proportions of micro- and macroaggregates $(0.05-1$

$316 \mathrm{~mm}$ ), indicating that the increase in SOC content facilitated aggregation and that micro- and

317 macroaggregates played an important role in stabilising the SOC content (Liu et al., 2016;

318 Tisdall and Oades, 1982). Mucilaginous substances released from organic fertilisers bind soil

319 particles into microaggregates and then into macroaggregates, which would increase the

320 proportions of the 0.1-0.25 mm and 0.25-0.5 size classes (Tisdall and Oades, 1982; Haynes and

321 Naidu, 1998; Tripathi et al., 2014). The long-term application of organic fertiliser also often

322 increases crop yield and above- and belowground biomass (Manna et al., 2007). Compounds

323 produced by roots and fungal hyphae, such as polysaccharides and other byproducts generated by

324 the decomposition of organic material in soil, can bind microaggregates together into

325 macroaggregates (Liao et al., 2006).

\section{Changes of $D_{v}$ and SOC content over time}

The long-term application of organic fertiliser increased SOC content from 1998 to 2012, in

agreement with the findings by Xu et al. (2016) and Banger et al. (2009), who attributed this 
331

332

333

334

335

336

337

338

339

340

341

342

343

344

345

346

347

348

349

organic and mineral fertilisers could substantially increase N, P, and K contents. Crop residues were removed in our study, so the long-term application of organic fertiliser may be the most effective option for improving and maintaining nutrient levels and soil quality.

\section{Conclusions}

Treatments receiving organic fertiliser increased the proportions of $0.1-0.25 \mathrm{~mm}$ microaggregates and $0.25-0.5 \mathrm{~mm}$ macroaggregates and correspondingly decreased the proportion of the $0.01-0.05 \mathrm{~mm}$ size class of the silt + clay fraction relative to CK, indicating that the application of organic fertiliser was favourable to the formation of larger aggregates. $D_{v}$ could not distinguish among the various treatments, because $D_{v}$ was mainly determined by the proportion of the $<0.002 \mathrm{~mm}$ size class of the silt + clay fraction that did not differ significantly among the treatments. SOC content was significantly higher in the treatments receiving organic fertiliser (M, MN, MP, and MNP) compared to those receiving mineral fertiliser, BL, and $\mathrm{CK}$ and tended to increase over time, which promoted the formation of larger aggregates and the sequestration of SOC. The application of organic fertiliser can thus contribute greatly to the improvement and sustainability of soil quality in semi-arid agricultural land when residues are removed.

\section{Acknowledgments}

We thank the anonymous reviewers and the journal editors for providing constructive comments and suggestions on the manuscript. 
350

351

352

353

354

355

356

357

358

359

360

361

362

363

364

365

366

367

368

369

370

\section{References}

Bai, J. H., H. F. Xu, R. Xiao, H. F. Gao, K. J. Zhang, and Q. Y. Ding. 2014. Path analysis for soil urease activities and nutrient contents in a Mountain Valley Wetland, China. Clean-Soil Air Water 42: 324-330.

Banger, K., S.S. Kukal, G. Toor, K. Sudhir, and T.H. Hanumanthraju. 2009. Impact of long-term additions of chemical fertilizers and farm yard manure on carbon and nitrogen sequestration under rice-cowpea cropping system in semi-arid tropics. Plant and Soil 318: 27-35.

Basta, N.T., D.J. Pantone, and M.A.Tabatabai. 1993. Path analysis of heavy metal adsorption by soil. Agronomy Journal, 85: 1054-1057.

Brar, B.S., K. Singh, G.S. Dheri, and K. Balwinder. 2013. Carbon sequestration and soil carbon pools in a ricewheat cropping system: Effect of long-term use of inorganic fertilizers and organic manure. Soil and Tillage Research 128: 30-36.

Celik, I., H.Gunal, M. Budak, and C. Akpinar. 2010. Effects of long-term organic and mineral fertilizers on bulk density and penetration resistance in semi-arid Mediterranean soil conditions. Geoderma 160: 236-243.

Chen, C., D.L. Chen, J.J. Pan, and S.K. Lam. 2014. Analysis of factors controlling soil $\mathrm{N}_{2} \mathrm{O}$ emission by principal component and path analysis method. Environmental Earth Sciences 72: 1511-1517.

Chen, X.Y., and J. Zhou. 2013. Volume-based soil particle fractal relation with soil erodibility in a small watershed of purple soil. Environmental Earth Sciences 70: 1735-1746.

Chenu, C., Y. Le Bissonnais, and D. Arrouays, 2000. Organic matter influence on clay wettability and soil aggregate stability. Soil Science Society of America Journal 64: 1479-1486.

FAO/UNESCO/ISRIC, 1988. Soil map of the world; revised legend. World Soil Resource Report, vol.60. FAO, Rome. 
371

372

373

374

375

376

377

378

379

380

381

382

383

384

385

386

387

388

389

390

391
Haynes, R.J., and R. Naidu. 1998. Influence of lime, fertilizer and manure applications on soil organic matter content and soil physical conditions: a review. Nutrient Cycling in Agroecosystems 51: 123-137.

Haynes, R.J., and R.S. Swift. 1990. Stability of soil aggregates in relation to organic constituents and soil water content. Journal of soil science 41: 73-83.

Helfrich, M., Ludwig, B., Thoms, C., Gleixner, G., Flessa, H., 2015. The role of soil fungi and bacteria in plant litter decomposition and macroaggregate formation determined using phospholipid fatty acids. Applied soil ecology $96: 261-264$.

Holeplass, H., B.R. Singh, and R. Lal. 2004. Carbon sequestration in soil aggregates under different crop rotations and nitrogen fertilization in an inceptisol in southeastern Norway. Nutrient Cycling in Agroecosystems 70: 167177.

Huang, S., X.X. Peng, Q.R. Huang, and W.J. Zhang. 2010. Soil aggregation and organic carbon fractions affected by long-term fertilization in a red soil of subtropical China. Geoderma 154: 364-369.

Ige, D.V., O.O. Akinremi, and D.N. Flaten. 2007. Direct and indirect effects of soil properties on phosphorus retention capacity. Soil Science Society of America Journal 71: 95-100.

Jaiarree, S., A. Chidthaisong, N. Polprasert, E. Sarobol, S. C. Tyler. 2014. Carbon Budget and sequestration potential in a sandy soil treated with compost. Land Degradation and Development 25:120-129.

Kuzyakov, Y., and W. Cheng. 2001. Photosynthesis controls of rhizosphere respiration and organic matter decomposition. Soil Biology and Biochemistry 33: 1915-1925.

Lal, R. 2004. Carbon sequestration in dryland ecosystems. Environmental management 33: 528-544.

Lenka, N.K., and R. Lal. 2013. Soil aggregation and greenhouse gas flux after 15 years of wheat straw and fertilizer management in a no-till system. Soil and Tillage Research 126: 78-89. 
392

393

394

395

396

397

398

399

400

401

402

403

404

405

406

407

408

409

410

411

412

Liu, E., J. Wang, Y. Zhang, D.A. Angers, C. Yan, T. Oweis, W. He, Q. Liu, B. Chen. 2015. Priming effect of (13)Clabelled wheat straw in no-tillage soil under drying and wetting cycles in the Loess Plateau of China.Scirntific report,5:13826.

Liu, Y.R., X. Li, Q.R. Shen, and Y.C. Xu. 2013. Enzyme Activity in Water-Stable Soil Aggregates as Affected by Long-Term Application of Organic Manure and Chemical Fertiliser. Pedosphere 23: 111-119.

Lugato, E., F. Simonetti, F. Morari, S. Nardi, A. Berti, and L. Giardini. 2010. Distribution of organic and humic carbon in wet-sieved aggregates of different soils under long-term fertilization experiment. Geoderma 157: 8085.

Majumder, B., J. Ruehlmann, and Y. Kuzyakov. 2010. Effects of aggregation processes on distribution of aggregate size fractions and organic C content of a long-term fertilized soil. European Journal of Soil Biology 46: 365370.

Mandelbrot, B.B. 1983. The fractal geometry of nature. Freeman, New York.

Manna, M.C., A. Swarup, R.H. Wanjari, B. Mishra, and D.K. Shahi. 2007. Long-term fertilization, manure and liming effects on soil organic matter and crop yields. Soil and Tillage Research 94: 397-409.

Martín, M.Á., and E. Montero. 2002. Laser diffraction and multifractal analysis for the characterization of dry soil volume-size distributions. Soil and Tillage Research 64: 113-123.

Miao, S.J., Y.F. Qiao, and L.R. Zhou. 2009. Aggregation stability and microbial activity of China's black soils under different long-term fertilisation regimes. New Zealand Journal of Agricultural Research 52: 57-67.

Sitzia, T., D. Pizzeghello, M. Dainese, A. Ertani, P. Carletti, P. Semenzato, S. Naedi, D. Cattaneo. 2014. Topsoil organic matter properties in contrasted hedgerowvegetation types. Pant and Soil 383: 337-348.

Nelson, D.W., and L.E. Sommers. 1982. Total carbon, organic carbon and organic matter. Agronomy Monograph 9. 
413

414

415

416

417

418

419

420

421

422

423

424

425

426

427

428

429

430

431

432

433

in: A.L. Page, R.H. Miller, D.R. Keeney (Eds), Methods of Soil Analysis, Part2,Chemical and Microbial Properties, Agronomy Society of America Madiso, Wisconsin, pp.539-552.

Paradelo, R., I. Virto, C. Chenu. 2015. Net effect of liming on soil organic carbon stocks: a review. Agriculture, Ecosystems and Environ 202:98-107.

Plaza-Bonilla, D., J. Alvaro-Fuentes, and C. Cantero-Martinez. 2013. Soil aggregate stability as affected by fertilization type under semiarid no-tillage conditions. Soil Science Society of America Journal 77, 284-292.

Rudrappa, L., T.J. Purakayastha, D. Singh, and S. Bhadraray. 2006. Long-term manuring and fertilization effects on soil organic carbon pools in a Typic Haplustept of semi-arid sub-tropical India. Soil and Tillage Research 88: 180-192.

Ryżak, M., and A. Bieganowski. 2011. Methodological aspects of determining soil particle - size distribution using the laser diffraction method. Journal of Plant Nutrition and Soil Science 174: 624-633.

Saha, D., Kukal, S.S., Bawa, S. S., 2014. Soil organic carbon stock and fractions in relation to land use and soil depth in the degraded Shiwaliks Hills of lower Himalayas. Land degradation and development 25: 407-416.

Silva, A.P., L.C. Babujia, Franchini, J.C., Ralisch, R., Hungria, M., Guimarães, M.F., 2014.Soil structure and its influence on microbial biomass in different soil and crop management systems. Soil and Tillage Research 147: $42-53$.

Su, Y.Z., F. Wang, D.R. Suo, Z.H. Zhang, and M.W. Du. 2006. Long-term effect of fertilizer and manure application on soil-carbon sequestration and soil fertility under the wheat-wheat-maize cropping system in northwest China. Nutrient Cycling in Agroecosystems 75: 285-295.

Tang, Y.Q., J. Li, X. H. Zhang, P. Yang, J. X. Wang, and N. Q. Zhou. 2013. Fractal characteristics and stability of soil aggregates in karst rocky desertification areas. Natural Hazards 65: 563-579. 
434 Tisdall, J., and J.M. Oades. 1982. Organic matter and water- stable aggregates in soils. Journal of soil science 33:

435

436

437

438

439

440

441

442

443

444

445

446

447

448

449

450

451

452

453

454
141-163.

Tripathi, R., A. K. Nayak, P. Bhattacharyya, A. K. Shukla, M. Shahid, R. Raja, B. B. Panda, S. Mohanty, A.Kumar, and V. K.Thilagam. 2014. Soil aggregation and distribution of carbon and nitrogen in different fractions after 41 years long-term fertilizer experiment in tropical rice-rice system. Geoderma 213: 280-286.

Tyler, S.W., and S.W. Wheatcraft. 1989. Application of fractal mathematics to soil water retention estimation. Soil Science Society of America Journal 53: 987-996.

Tyler, S.W., and S.W. Wheatcraft. 1992. Fractal scaling of soil particle-size distributions: analysis and limitations. Soil Science Society of America Journal 56: 362-369.

Wang, G.L., S.L. Zhou, and Q.G. Zhao. 2005. Volume fractal dimension of soil particles and its applications to land use (in Chinese). Acta Pedologica Sinica 42: 545-550.

Whalen, J.K., Q. Hu, and A. Liu. 2003. Manure applications improve aggregate stability in conventional and notillage systems. Soil Science Society of America Journal 67: 1842-1847.

Williams, W.A., M.W. Demment, and M.B. Jones. 1990. A concise table for path analysis statistics. Agronomy Journal 82: 1022-1024.

Wright, S. 1934. The method of path coefficients. The Annals of Mathematical Statistics, 5: 161-215.

Xiao, L., S. Xue, S, G.B. Liu, and C. Zhang. 2014. Fractal features of soil profiles under different land use patterns on the Loess Plateau, China. Journal of Arid Land 6: 550-560.

Xu, X. R., W. J. Zhang, M. G. Xu., S. Y. Li., T. T. An, J. B. Pei, J. Xiao, H. T. Xie, J. K. Wang.2016. Characteristics of differently stabilised soil organic carbon fractions in relation to long-term fertilisation in Brown Earth of Northeast China. Science of the Total Environment 572:1101-1110. 
455

456

457

458

459

460

461

462

463

464

465

466

467

468

Yang, X.M., X.P. Zhang, H.J. Fang, P. Zhu, J. Ren, and L.C. Wang. 2003. Long-term effects of fertilization on soil organic carbon changes in continuous corn of northeast China: RothC model simulations. Environmental management 32: 459-465.

Yu, H.Y., W.X. Ding, J.F. Luo, R.L. Geng, and Z.C. Cai. 2012. Long-term application of organic manure and mineral fertilizers on aggregation and aggregate-associated carbon in a sandy loam soil. Soil and Tillage Research 124: 170-177.

Zhang, H., J. L.Schroder, J. K. Fuhrman, N. T. Basta, D. E. Storm, and M. E. Payton. 2005. Path and multiple regression analyses of phosphorus sorption capacity. Soil Science Society of America Journal 69: 96-106.

Zhao, S.W., J. Su, Y.H. Yang, N.N. Liu, J.S. Wu, and Z.P. Shangguan. 2006. A fractal method of estimating soil structure changes under different vegetations on Ziwuling Mountains of the Loess Plateau, China. Agricultural Sciences in China 5: 530-538.

Zhu, B.B., Z.B. Li, P. Li, G.B. Liu, and S. Xue, 2010. Soil erodibility, microbial biomass, and physical-chemical property changes during long-term natural vegetation restoration: a case study in the Loess Plateau, China. Ecological Research 25: 531-541. 


\section{Table $\mathbf{1}$ (on next page)}

The amounts of fertilisers applied in long-term experiment $\left(\mathrm{kg} \mathrm{ha}^{-1}\right)$

$\mathrm{N}$ was added as urea, $\mathrm{P}$ as superphosphate, and the farmyard manure contained the feces and urine from domestic sheep. BL represents bare land (no plants nor fertilisers) and CK represents unfertilised control. Contents of organic matter, $\mathrm{N}$ and $\mathrm{P}$ in feces were 25.7, 0.75, and $0.54 \%$ respectively. Contents of $\mathrm{N}$ and $\mathrm{P}$ in urine were 1.4 and $0.45 \%$ respectively. 
1 Table 1

2 The amounts of fertilisers applied in long-term experiment $\left(\mathrm{kg} \mathrm{ha}^{-1}\right)$

\begin{tabular}{llll}
\hline Treatments & $\begin{array}{l}\text { Organic } \\
\text { manure }\end{array}$ & N fertiliser & P fertiliser \\
\hline BL & 0 & 0 & 0 \\
CK & 0 & 0 & 0 \\
M & 7500 & 0 & 0 \\
MN & 7500 & 211.95 & 0 \\
MNP & 7500 & 211.95 & 166.65 \\
MP & 7500 & 0 & 166.65 \\
N & 0 & 211.95 & 0 \\
NP & 0 & 211.95 & 166.65 \\
P & 0 & 0 & 166.65
\end{tabular}

Note: $\mathrm{N}$ was added as urea, $\mathrm{P}$ as superphosphate, and the farmyard manure contained the feces and urine from domestic sheep. BL represents bare land (no plants nor fertilisers) and CK represents unfertilised control. Contents of organic matter, $\mathrm{N}$ and $\mathrm{P}$ in feces were $25.7,0.75$, and $0.54 \%$ respectively. Contents of $\mathrm{N}$ and $\mathrm{P}$ in urine were 1.4 and $0.45 \%$ respectively. 
Table 2 (on next page)

Effects of fertilizer treatments on aggregates, fractal dimension $\left(D_{v}\right)$ and soil organic carbon content (SOC) 
Table 2

Effects of fertilizer treatments on aggregates, fractal dimension $\left(D_{v}\right)$ and soil organic carbon content (SOC)

\begin{tabular}{|c|c|c|c|c|c|c|c|c|c|c|c|c|}
\hline $\begin{array}{l}\text { Treatmen } \\
\text { ts }\end{array}$ & $\begin{array}{l}<0.002 \\
\mathrm{~mm}\end{array}$ & $\begin{array}{l}0.002- \\
0.005 \\
\mathrm{~mm}\end{array}$ & $\begin{array}{l}0.005- \\
0.01 \\
\mathrm{~mm}\end{array}$ & $\begin{array}{l}0.01-0.02 \\
\mathrm{~mm}\end{array}$ & $\begin{array}{l}0.02-0.05 \\
\mathrm{~mm}\end{array}$ & $\begin{array}{l}0.05-0.1 \\
\mathrm{~mm}\end{array}$ & $\begin{array}{l}0.1-0.2 \\
\mathrm{~mm}\end{array}$ & $\begin{array}{l}0.2-0.25 \\
\mathrm{~mm}\end{array}$ & $\begin{array}{l}0.25-0.5 \\
\mathrm{~mm}\end{array}$ & $\begin{array}{l}0.5-1 \\
\mathrm{~mm}\end{array}$ & $D_{v}$ & SOC (\%) \\
\hline $\mathrm{BL}$ & $\begin{array}{l}4.13 \pm 0.2 \\
9\end{array}$ & $\begin{array}{l}6.11 \pm 0.5 \\
5\end{array}$ & $7.1 \pm 0.56$ & $\begin{array}{l}10.17 \pm 0.69 \\
\text { ab }\end{array}$ & $\begin{array}{l}33.91 \pm 0.54 \\
\text { ab }\end{array}$ & $\begin{array}{l}27.46 \pm 1.11 \\
\mathrm{ab}\end{array}$ & $\begin{array}{l}7.46 \pm 0.65 b \\
\mathrm{~cd}\end{array}$ & $\begin{array}{l}0.37 \pm 0.07 b \\
\mathrm{c}\end{array}$ & $\begin{array}{l}2.14 \pm 0.37 \mathrm{a} \\
\mathrm{b}\end{array}$ & $\begin{array}{l}1.14 \pm 0.3 \\
7\end{array}$ & $\begin{array}{l}2.736 \pm 0.0 \\
0\end{array}$ & $\begin{array}{l}0.58 \pm 0.05 \\
d\end{array}$ \\
\hline CK & $\begin{array}{l}4.42 \pm 0.0 \\
1\end{array}$ & $\begin{array}{l}6.44 \pm 0.1 \\
4\end{array}$ & $\begin{array}{l}7.31 \pm 0.2 \\
1\end{array}$ & $\begin{array}{l}10.52 \pm 0.25 \\
\text { ab }\end{array}$ & $\begin{array}{l}34.90 \pm 0.84 \\
\mathrm{a}\end{array}$ & $\begin{array}{l}27.04 \pm 0.77 \\
\mathrm{ab}\end{array}$ & $\begin{array}{l}7.08 \pm 0.13 \mathrm{c} \\
\mathrm{d}\end{array}$ & $\begin{array}{l}0.38 \pm 0.07 \mathrm{~b} \\
\mathrm{c}\end{array}$ & $\begin{array}{l}1.36 \pm 0.52 \\
\mathrm{~b}\end{array}$ & $\begin{array}{l}0.56 \pm 0.2 \\
8\end{array}$ & $\begin{array}{l}2.736 \pm 0.0 \\
0\end{array}$ & $\begin{array}{l}0.65 \pm 0.03 \mathrm{c} \\
\mathrm{d}\end{array}$ \\
\hline M & $4.00 \pm 0.3$ & $\begin{array}{l}5.97 \pm 0.5 \\
9\end{array}$ & $\begin{array}{l}6.93 \pm 0.4 \\
7\end{array}$ & $9.73 \pm 0.37 \mathrm{~b}$ & $\begin{array}{l}32.74 \pm 0.94 \\
\mathrm{c}\end{array}$ & $\begin{array}{l}27.87 \pm 1.32 \\
\mathrm{ab}\end{array}$ & $8.79 \pm 0.25 \mathrm{a}$ & $0.81 \pm 0.31 \mathrm{a}$ & $2.31 \pm 0.21 \mathrm{a}$ & $\begin{array}{l}0.87 \pm 0.1 \\
6\end{array}$ & $\begin{array}{l}2.735 \pm 0.0 \\
1\end{array}$ & $0.97 \pm 0.08 \mathrm{a}$ \\
\hline MN & $\begin{array}{l}4.09 \pm 0.3 \\
9\end{array}$ & $\begin{array}{l}6.05 \pm 0.7 \\
1\end{array}$ & $\begin{array}{l}7.10 \pm 0.6 \\
1\end{array}$ & $\begin{array}{l}10.27 \pm 0.6 \mathrm{a} \\
\mathrm{b}\end{array}$ & $\begin{array}{l}33.92 \pm 0.24 \\
\text { ab }\end{array}$ & $\begin{array}{l}26.93 \pm 0.91 \\
\mathrm{ab}\end{array}$ & $\begin{array}{l}7.76 \pm 0.39 b \\
c\end{array}$ & $\begin{array}{l}0.58 \pm 0.05 \mathrm{a} \\
\mathrm{bc}\end{array}$ & $2.23 \pm 0.57 \mathrm{a}$ & $\begin{array}{l}1.05 \pm 0.4 \\
7\end{array}$ & $\begin{array}{l}2.735 \pm 0.0 \\
1\end{array}$ & $\begin{array}{l}0.90 \pm 0.01 \mathrm{a} \\
\mathrm{b}\end{array}$ \\
\hline MNP & $\begin{array}{l}4.00 \pm 0.1 \\
5\end{array}$ & $\begin{array}{l}5.94 \pm 0.3 \\
3\end{array}$ & $\begin{array}{l}6.95 \pm 0.2 \\
4\end{array}$ & $9.96 \pm 0.15 \mathrm{~b}$ & $\begin{array}{l}33.74 \pm 0.59 \\
\text { bc }\end{array}$ & $\begin{array}{l}27.3 \pm 0.36 \mathrm{a} \\
\mathrm{b}\end{array}$ & $\begin{array}{l}7.99 \pm 0.15 \mathrm{a} \\
\mathrm{b}\end{array}$ & $0.67 \pm 0.2 \mathrm{ab}$ & $2.39 \pm 0.46 \mathrm{a}$ & $\begin{array}{l}1.05 \pm 0.1 \\
2\end{array}$ & $\begin{array}{l}2.734 \pm 0.0 \\
1\end{array}$ & $\begin{array}{l}0.87 \pm 0.03 \\
\mathrm{~b}\end{array}$ \\
\hline MP & $\begin{array}{l}3.99 \pm 0.1 \\
6\end{array}$ & $\begin{array}{l}5.93 \pm 0.3 \\
1\end{array}$ & $\begin{array}{l}6.95 \pm 0.4 \\
3\end{array}$ & $\begin{array}{l}10.00 \pm 0.63 \\
\text { b }\end{array}$ & $\begin{array}{l}33.62 \pm 0.31 \\
\text { bc }\end{array}$ & $\begin{array}{l}27.19 \pm 0.85 \\
\text { ab }\end{array}$ & $\begin{array}{l}8.03 \pm 0.29 \mathrm{a} \\
\mathrm{b}\end{array}$ & $\begin{array}{l}0.70 \pm 0.24 \mathrm{a} \\
\mathrm{b}\end{array}$ & $2.41 \pm 0.45 \mathrm{a}$ & $\begin{array}{l}1.18 \pm 0.5 \\
9\end{array}$ & $\begin{array}{l}2.734 \pm 0.0 \\
0\end{array}$ & $\begin{array}{l}0.93 \pm 0.06 \mathrm{a} \\
\mathrm{b}\end{array}$ \\
\hline $\mathrm{N}$ & $\begin{array}{l}4.08 \pm 0.4 \\
3\end{array}$ & $\begin{array}{l}5.97 \pm 0.7 \\
9\end{array}$ & $\begin{array}{l}7.03 \pm 0.6 \\
6\end{array}$ & $\begin{array}{l}10.26 \pm 0.55 \\
\mathrm{ab}\end{array}$ & $\begin{array}{l}34.58 \pm 0.23 \\
\mathrm{ab}\end{array}$ & $\begin{array}{l}27.61 \pm 0.89 \\
\mathrm{ab}\end{array}$ & $\begin{array}{l}7.33 \pm 0.48 b \\
\text { cd }\end{array}$ & $0.30 \pm 0.16 \mathrm{c}$ & $\begin{array}{l}1.90 \pm 0.44 \mathrm{a} \\
\mathrm{b}\end{array}$ & $\begin{array}{l}0.94 \pm 0.2 \\
7\end{array}$ & $\begin{array}{l}2.732 \pm 0.0 \\
1\end{array}$ & $\begin{array}{l}0.63 \pm 0.04 \mathrm{c} \\
\mathrm{d}\end{array}$ \\
\hline NP & $\begin{array}{l}4.30 \pm 0.1 \\
8\end{array}$ & $\begin{array}{l}6.43 \pm 0.3 \\
6\end{array}$ & $7.7 \pm 0.63$ & $\begin{array}{l}11.23 \pm 1.05 \\
\mathrm{a}\end{array}$ & $\begin{array}{l}34.59 \pm 0.56 \\
\mathrm{ab}\end{array}$ & $\begin{array}{l}26.22 \pm 1.11 \\
\mathrm{~b}\end{array}$ & $6.82 \pm 0.81 \mathrm{~d}$ & $0.30 \pm 0.19 \mathrm{c}$ & $\begin{array}{l}1.70 \pm 0.37 \mathrm{a} \\
\mathrm{b}\end{array}$ & $\begin{array}{l}0.71 \pm 0.2 \\
7\end{array}$ & $\begin{array}{l}2.735 \pm 0.0 \\
0\end{array}$ & $0.67 \pm 0.05 \mathrm{c}$ \\
\hline$P$ & $\begin{array}{l}4.03 \pm 0.2 \\
5\end{array}$ & $5.9 \pm 0.47$ & $\begin{array}{l}6.81 \pm 0.4 \\
1\end{array}$ & $9.71 \pm 0.33 b$ & $\begin{array}{l}33.99 \pm 0.29 \\
\mathrm{ab}\end{array}$ & $\begin{array}{l}28.45 \pm 0.47 \\
\mathrm{a}\end{array}$ & $\begin{array}{l}8.13 \pm 0.41 \mathrm{a} \\
\mathrm{b}\end{array}$ & $\begin{array}{l}0.43 \pm 0.13 b \\
c\end{array}$ & $\begin{array}{l}1.82 \pm 0.56 \mathrm{a} \\
\mathrm{b}\end{array}$ & $\begin{array}{l}0.72 \pm 0.3 \\
8\end{array}$ & $\begin{array}{l}2.732 \pm 0.0 \\
1\end{array}$ & $0.67 \pm 0.02 \mathrm{c}$ \\
\hline F value & 0.906 & 0.509 & 0.856 & 1.963 & $3.966^{* *}$ & 1.409 & $5.456^{* *}$ & $3.372 * *$ & 1.907 & 1.123 & 0.279 & $32.983 * *$ \\
\hline CV (\%) & 3.42 & 3.25 & 3.54 & 4.30 & 1.78 & 2.16 & 7.39 & 35.43 & 16.62 & 22.08 & 0.05 & 18.64 \\
\hline
\end{tabular}

** significant at $P<0.01$ 


\section{Table 3(on next page)}

Correlations relationship of aggregates, fractal dimension $\left(D_{v}\right)$ and soil organic carbon content (SOC) 
1 Table 3

2 Correlations relationship of aggregates, fractal dimension $\left(D_{v}\right)$ and soil organic carbon content (SOC)

\begin{tabular}{|c|c|c|c|c|c|c|c|c|c|c|c|c|}
\hline \multirow{2}{*}{$\begin{array}{l}\text { Fractions } \\
\text { Particle size }\end{array}$} & \multicolumn{5}{|c|}{ Silt and clay fraction } & \multicolumn{3}{|c|}{ Microaggregates } & \multicolumn{2}{|c|}{ Macroaggregates } & \multirow[b]{2}{*}{$D_{v}$} & \multirow[b]{2}{*}{$\begin{array}{l}\text { SOC } \\
(\%)\end{array}$} \\
\hline & $\begin{array}{l}<0.002 \\
\mathrm{~mm}\end{array}$ & $\begin{array}{l}0.002-0.005 \\
\mathrm{~mm}\end{array}$ & $\begin{array}{l}0.005-0.01 \\
\mathrm{~mm}\end{array}$ & $\begin{array}{l}0.01-0.02 \\
\mathrm{~mm}\end{array}$ & $\begin{array}{l}0.02-0.05 \\
\mathrm{~mm}\end{array}$ & $\begin{array}{l}0.05-0.1 \\
\mathrm{~mm}\end{array}$ & $\begin{array}{l}0.1-0.2 \\
\mathrm{~mm}\end{array}$ & $\begin{array}{l}0.2-0.25 \\
\mathrm{~mm}\end{array}$ & $\begin{array}{l}0.25-0.5 \\
\mathrm{~mm}\end{array}$ & $\begin{array}{l}0.5-1 \\
\mathrm{~mm}\end{array}$ & & \\
\hline $\begin{array}{l}<0.002 \\
\mathrm{~mm}\end{array}$ & 1 & & & & & & & & & & & \\
\hline $\begin{array}{l}0.002-0.005 \\
\mathrm{~mm}\end{array}$ & $0.844 * *$ & 1 & & & & & & & & & & \\
\hline $\begin{array}{l}0.005-0.01 \\
\mathrm{~mm}\end{array}$ & $0.826^{* *}$ & $0.834 * *$ & 1 & & & & & & & & & \\
\hline $\begin{array}{l}0.01-0.02 \\
\mathrm{~mm}\end{array}$ & $0.529^{* *}$ & $0.597 * *$ & $0.701 * *$ & 1 & & & & & & & & \\
\hline $\begin{array}{l}0.02-0.05 \\
\mathrm{~mm}\end{array}$ & 0.075 & $0.235^{* *}$ & 0.020 & $0.624 * *$ & 1 & & & & & & & \\
\hline $\begin{array}{l}0.05-0.1 \\
\mathrm{~mm}\end{array}$ & $-0.421^{* *}$ & $-0.657 * *$ & $-0.478 * *$ & $-0.803^{* *}$ & $-0.732 * *$ & 1 & & & & & & \\
\hline $\begin{array}{l}0.1-0.2 \\
\mathrm{~mm}\end{array}$ & $-0.353^{* *}$ & $-0.520^{* *}$ & $-0.313^{* *}$ & $-0.748^{* *}$ & $-0.865^{* *}$ & $0.881^{* *}$ & 1 & & & & & \\
\hline $\begin{array}{l}0.2-0.25 \\
\mathrm{~mm}\end{array}$ & $-0.266^{* *}$ & -0.080 & $-0.220^{* *}$ & -0.080 & 0.138 & $-0.263 * *$ & 0.075 & 1 & & & & \\
\hline $\begin{array}{l}0.25-0.5 \\
\mathrm{~mm}\end{array}$ & $-0.439 * *$ & $-0.358 * *$ & $-0.416^{* *}$ & $-0.503 * *$ & $-0.446^{* *}$ & $0.185^{*}$ & $0.237 * *$ & 0.129 & 1 & & & \\
\hline $0.5-1 \mathrm{~mm}$ & $-0.474 * *$ & $-0.454 * *$ & $-0.423 * *$ & $-0.589 * *$ & $-0.584 * *$ & $0.396^{* *}$ & $0.413^{* *}$ & -0.064 & $0.861 * *$ & 1 & & \\
\hline$D_{v}$ & $0.756^{* *}$ & $0.646^{* *}$ & $0.623 * *$ & 0.051 & $-0.467 * *$ & -0.106 & 0.055 & $-0.203 *$ & $0.165^{*}$ & 0.142 & 1 & \\
\hline SOC (\%) & $-0.244 * *$ & $-0.177 *$ & -0.155 & $-0.358 * *$ & $-0.434 * *$ & $0.207 *$ & $0.490 * *$ & $0.500 * *$ & $0.340^{* *}$ & $0.310^{* *}$ & 0.098 & 1 \\
\hline
\end{tabular}




\section{Table 4 (on next page)}

Direct effects (diagonal, underlined) and indirect effects (off-diagonal) of aggregates on fractal dimension $\left(D_{v}\right)$ 
Table 4

Direct effects (diagonal, underlined) and indirect effects (off-diagonal) of aggregates on fractal dimension $\left(D_{v}\right)$.

\begin{tabular}{|c|c|c|c|c|c|c|c|c|c|c|c|c|}
\hline Variable & $r$ & $\begin{array}{l}<0.002 \\
\mathrm{~mm}\end{array}$ & $\begin{array}{l}0.002- \\
0.005 \mathrm{~mm}\end{array}$ & $\begin{array}{l}0.005- \\
0.01 \mathrm{~mm}\end{array}$ & $\begin{array}{l}0.05- \\
0.1 \mathrm{~mm}\end{array}$ & $\begin{array}{l}0.1- \\
0.2 \mathrm{~mm}\end{array}$ & $\begin{array}{l}0.2- \\
0.25 \mathrm{~mm}\end{array}$ & $\begin{array}{l}0.25- \\
0.5 \mathrm{~mm}\end{array}$ & $\begin{array}{l}0.5-1 \\
\mathrm{~mm}\end{array}$ & Total & $U$ & $R^{2}$ \\
\hline $\begin{array}{l}<0.002 \\
\mathrm{~mm}\end{array}$ & $0.756^{* *}$ & $\underline{0.887}^{* *}$ & 0.311 & 0.045 & -0.123 & -0.039 & -0.030 & -0.167 & -0.130 & -0.132 & \multirow[t]{8}{*}{0.054} & \multirow[t]{8}{*}{0.997} \\
\hline $\begin{array}{l}0.002- \\
0.005 \mathrm{~mm}\end{array}$ & $0.646^{* *}$ & 0.749 & $\underline{0.368^{* *}}$ & 0.046 & -0.191 & -0.057 & -0.009 & -0.136 & -0.124 & 0.277 & & \\
\hline $\begin{array}{l}0.005- \\
0.01 \mathrm{~mm}\end{array}$ & $0.623^{* *}$ & 0.732 & 0.307 & $\underline{0.055}^{* *}$ & -0.139 & -0.034 & -0.025 & -0.158 & -0.116 & 0.586 & & \\
\hline $\begin{array}{l}0.05-0.1 \\
\mathrm{~mm}\end{array}$ & -0.106 & -0.374 & -0.242 & -0.026 & $\underline{0.291}^{* *}$ & 0.096 & -0.029 & 0.070 & 0.108 & -0.396 & & \\
\hline $\begin{array}{l}0.1-0.2 \\
\mathrm{~mm}\end{array}$ & 0.055 & -0.313 & -0.191 & -0.017 & 0.256 & $\underline{0.109}^{* *}$ & 0.008 & 0.090 & 0.113 & -0.054 & & \\
\hline $\begin{array}{l}0.2-0.25 \\
\mathrm{~mm}\end{array}$ & $-0.203^{*}$ & -0.236 & -0.030 & -0.012 & -0.077 & 0.008 & ${\underline{0.112^{* *}}}^{*}$ & 0.049 & -0.017 & -0.314 & & \\
\hline $\begin{array}{l}0.25-0.5 \\
\mathrm{~mm}\end{array}$ & $0.165^{*}$ & -0.389 & -0.132 & -0.023 & 0.054 & 0.026 & 0.014 & $\underline{0.380}^{* *}$ & 0.236 & -0.214 & & \\
\hline $\begin{array}{l}0.5-1 \\
\mathrm{~mm}\end{array}$ & 0.142 & -0.421 & -0.167 & -0.023 & 0.115 & 0.045 & -0.007 & 0.327 & $\underline{0.274}^{* *}$ & -0.131 & & \\
\hline
\end{tabular}

*.significant at $P<0.05$. ** significant at $P<0.01$

$r$ : correlation coefficients between micro-aggregate fractions and fractal dimension; Total: total indirect path coefficient; $U$ : uncorrelated residue. 
Table 5 (on next page)

The determination coefficients of each factor 
1 Table 5

2 The determination coefficients of each factor

\begin{tabular}{|c|c|c|c|c|c|c|c|c|}
\hline \multirow{2}{*}{$\begin{array}{l}\text { Fractions } \\
\text { Particle size }\end{array}$} & \multicolumn{3}{|c|}{ Silt and clay fraction } & \multicolumn{3}{|c|}{ Microaggregates } & \multicolumn{2}{|c|}{ Macroaggregates } \\
\hline & $\begin{array}{l}<0.002 \\
\mathrm{~mm}\end{array}$ & $\begin{array}{l}0.002-0.005 \\
\mathrm{~mm}\end{array}$ & $\begin{array}{l}0.005-0.01 \\
\mathrm{~mm}\end{array}$ & $\begin{array}{l}0.05-0.1 \\
\mathrm{~mm}\end{array}$ & $\begin{array}{l}0.1-0.2 \\
\mathrm{~mm}\end{array}$ & $\begin{array}{l}0.2-0.25 \\
\mathrm{~mm}\end{array}$ & $\begin{array}{l}0.25-0.5 \\
\mathrm{~mm}\end{array}$ & $\begin{array}{l}0.5-1 \\
\mathrm{~mm}\end{array}$ \\
\hline $\begin{array}{l}<0.002 \\
\mathrm{~mm}\end{array}$ & 0.787 & 0.653 & 0.098 & 0.516 & 0.193 & 0.199 & 0.674 & 0.486 \\
\hline $\begin{array}{l}0.002-0.005 \\
\mathrm{~mm}\end{array}$ & & 0.135 & 0.040 & 0.214 & 0.080 & 0.082 & 0.280 & 0.202 \\
\hline $\begin{array}{l}0.005-0.01 \\
\mathrm{~mm}\end{array}$ & & & 0.003 & 0.032 & 0.012 & 0.012 & 0.042 & 0.030 \\
\hline $\begin{array}{l}0.05-0.1 \\
\mathrm{~mm}\end{array}$ & & & & 0.085 & 0.063 & 0.065 & 0.221 & 0.159 \\
\hline $\begin{array}{l}0.1-0.2 \\
\mathrm{~mm}\end{array}$ & & & & & 0.012 & 0.024 & 0.083 & 0.060 \\
\hline $\begin{array}{l}0.2-0.25 \\
\mathrm{~mm}\end{array}$ & & & & & & 0.013 & 0.085 & 0.061 \\
\hline $\begin{array}{l}0.25-0.5 \\
\mathrm{~mm}\end{array}$ & & & & & & & 0.144 & 0.208 \\
\hline $\begin{array}{l}0.5-1 \\
\mathrm{~mm}\end{array}$ & & & & & & & & 0.075 \\
\hline
\end{tabular}

3

4 
Figure 1

Scheme showing the experimental area with various fertiliser treatments

Note: Mineral fertilizers were nitrogen $(N)$ and phosphorus $(P)$, organic fertilizer was farmyard manure (M). Treatments were mineral fertilizers, organic manure, different combinations of mineral fertilizers and organic manure, unfertilized bare land (BL) and an unfertilized control (CK).

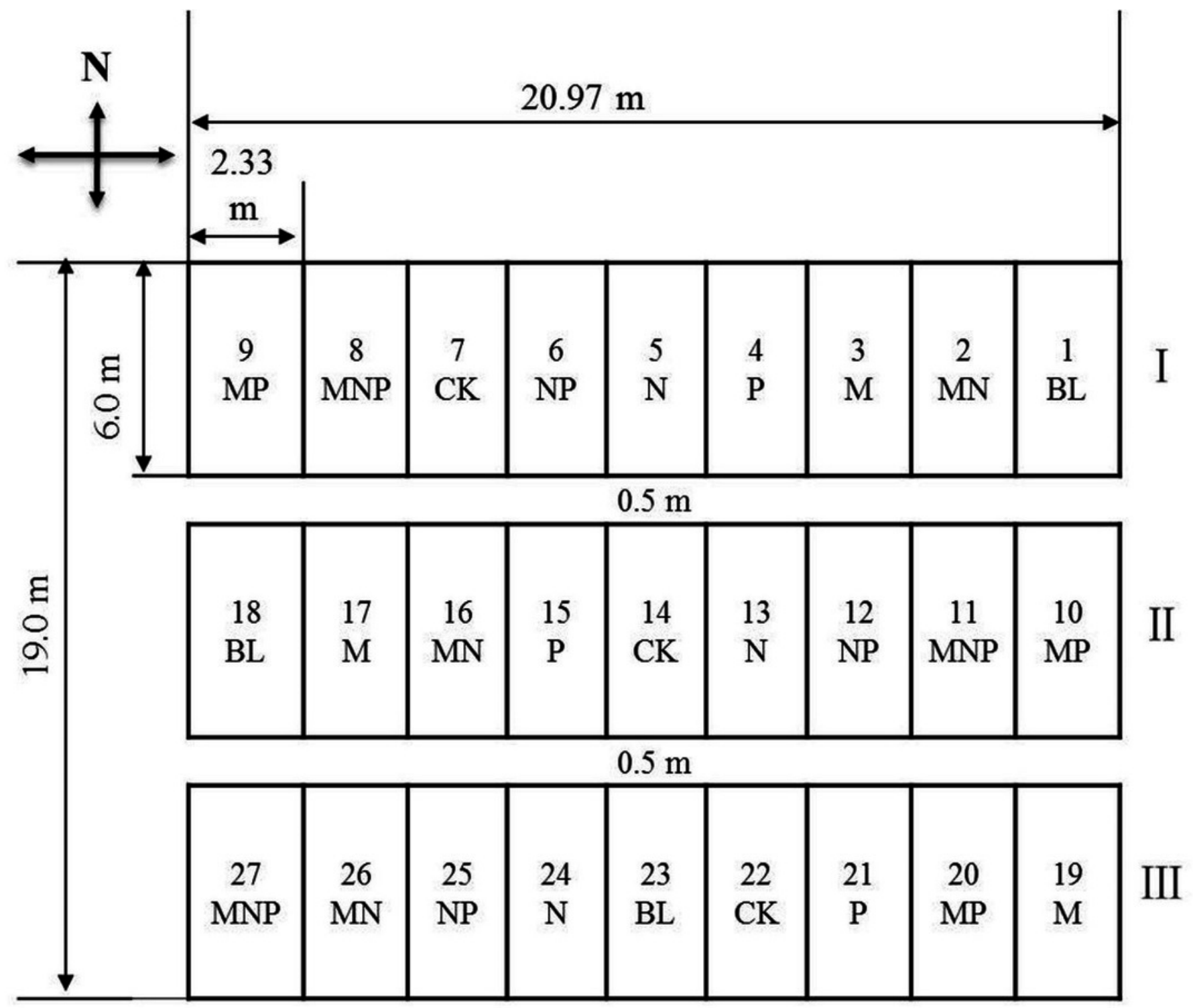


Figure 2

Path analysis diagram for the relationships between fractal dimension and microaggregate fractions

Note: Direct path coefficients $\left(P_{i j}\right)$ of micro-aggregate fractions are presented by singleheaded arrows while simple correlation coefficients $\left(r_{i j}\right)$ between variables are represented by double-headed arrows. Subscript designations of 1 to 9 are $<0.002,0.002-0.005,0.005-0.01$, 0.05-0.1, 0.1-0.2, 0.2-0.25, 0.25-0.5, 0.5-1 mm micro-aggregates, and fractal dimension $\left(D_{\vee}\right)$, respectively.

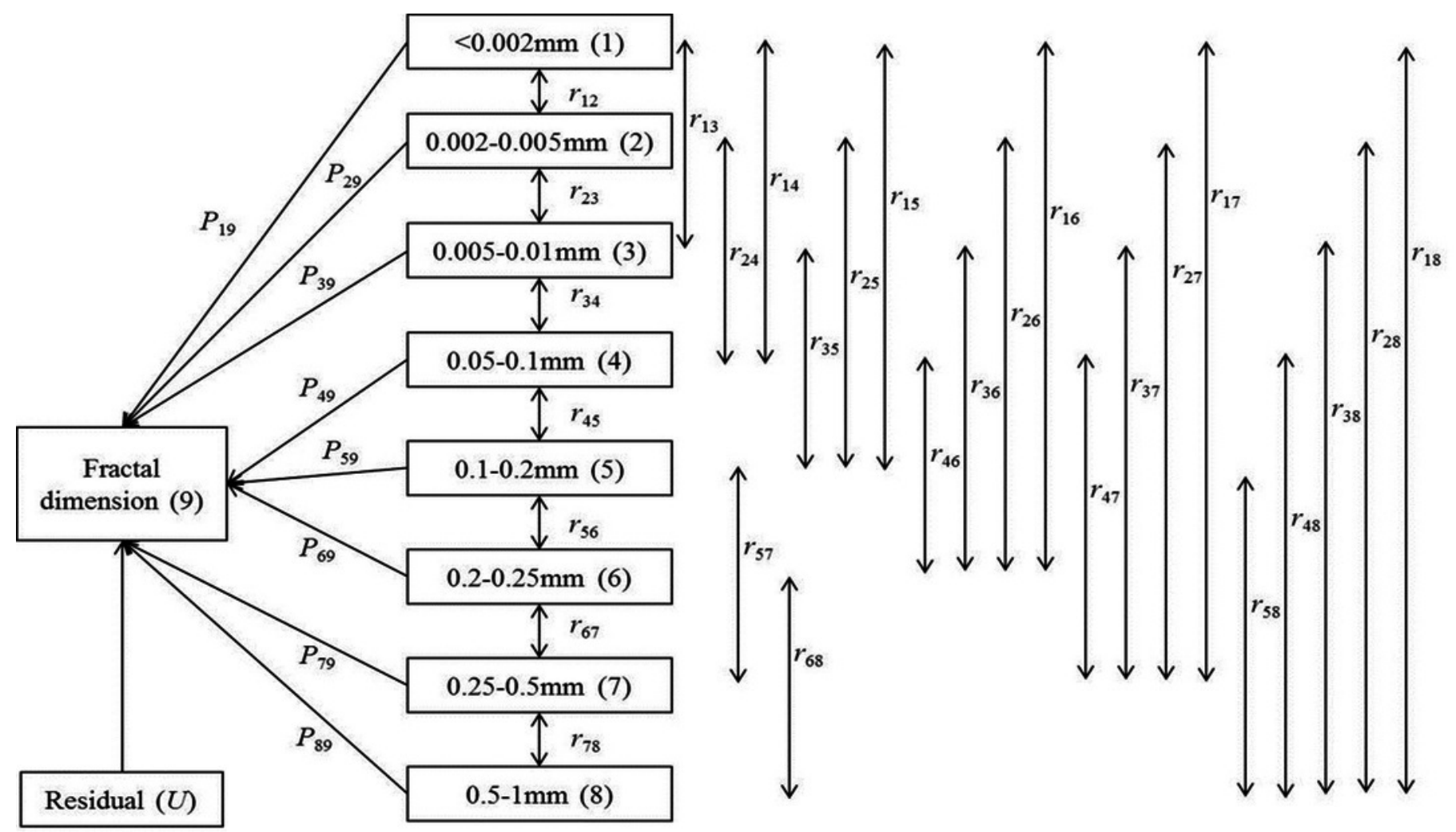


Figure 3

Changes of fractal dimension and SOC content in different fertilizer treatments from 1998 to 2012

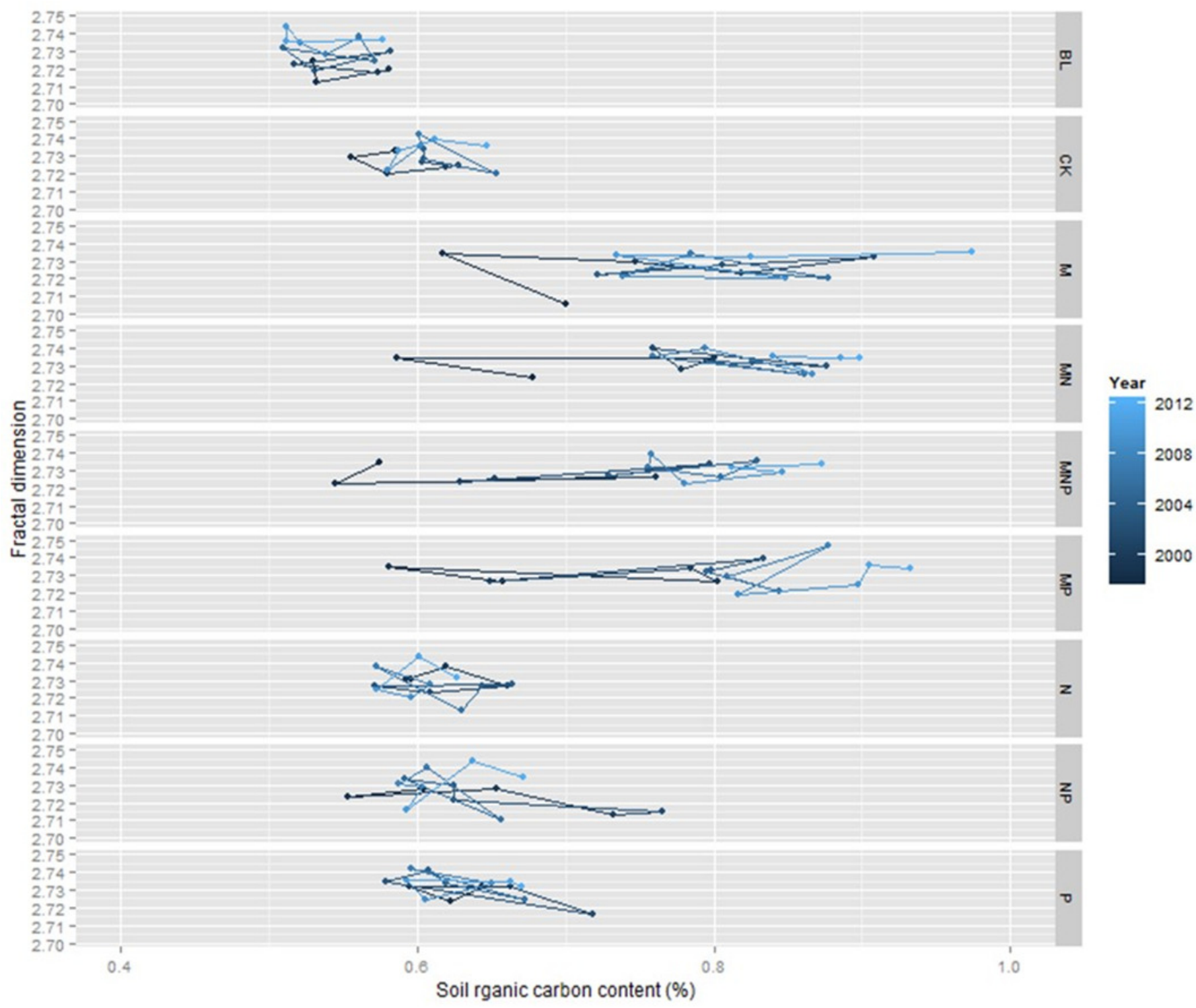

